\title{
Classification and genetic features of neonatal haemochromatosis: a study of 27 affected pedigrees and molecular analysis of genes implicated in iron metabolism
}

Alison L Kelly, Peter W Lunt, Fernanda Rodrigues, P J Berry, Diana M Flynn, Patrick J McKiernan, Deirdre A Kelly, Giorgina Mieli-Vergani, Timothy M Cox

Department of Medicine, University of Cambridge, Level 5, Box 157,

Addenbrooke's Hospital, Cambridge CB2 2QQ, UK

A L Kelly

T M Cox

Clinical Genetics Service, Institute of Child Health, Bristol Royal Hospital for Sick Children, St Michael's Hill, Bristol BS2 8BJ, UK

P W Lunt

University of Bristol, Department of Paediatric Pathology, St Michael's Hospital, Southwell Street, Bristol BS2 8EG, UK P J Berry

Paediatric Liver Service, King's College Hospital, Denmark Hill, London SE5 9RS, UK

F Rodrigues

G Mieli-Vergani

The Liver Unit, The Birmingham Children's Hospital

NHS Trust, Steelhouse Lane, Birmingham

B4 6NH, UK

D M Flynn

P J McKiernan

D A Kelly

Correspondence to: Professor T M Cox, jbg@medschl.cam.ac.uk

Revised version received 15 June 2001

Accepted for publication

18 June 2001

\section{Abstract}

Neonatal haemochromatosis (NH) is a severe and newly recognised syndrome of uncertain aetiology, characterised by congenital cirrhosis or fulminant hepatitis and widespread tissue iron deposition. $\mathrm{NH}$ occurs in the context of maternal disease including viral infection, as a complication of metabolic disease in the fetus, and sporadically or recurrently, without overt cause, in sibs. Although an underlying genetic basis for NH has been suspected, no test is available for predictive analysis in at risk pregnancies.

As a first step towards an understanding of the putative genetic basis for neonatal haemochromatosis, we have conducted a systematic study of the mode of transmission of this disorder in a total of 40 infants born to 27 families. We have moreover carried out a molecular analysis of candidate genes $\left(\beta_{2}\right.$-microglobulin, $H F E$, and haem oxygenases 1 and 2) implicated in iron metabolism. No pathogenic mutations in these genes were identified that segregate consistently with the disease phenotype in multiplex pedigrees. However, excluding four pedigrees with clear evidence of maternal infection associated with $\mathrm{NH}$, a pedigree showing transmission of maternal antinuclear factor and ribonucleoprotein antibodies to the affected infants, and two families with possible matrilineal inheritance of disease in maternal half sibs, a large subgroup of the affected pedigrees point to the inheritance of an autosomal recessive trait. This included 14 pedigrees with affected and unaffected infants and a single pedigree where all four affected infants were the sole offspring of consanguineous but otherwise healthy parents.

We thus report three distinct patterns of disease transmission in neonatal haemochromatosis. In the differentiation of a large subgroup showing transmission of disease in a manner suggesting autosomal recessive inheritance, we also provide the basis for further genome wide studies to define chromosomal determinants of iron storage disease in the newborn. (f Med Genet 2001;38:599-610)

Keywords: iron storage; haemochromatosis; neonatal; liver
Neonatal haemochromatosis (NH, Online Mendelian Inheritance in Man, OMIM 231100) is a newly recognised and rare syndrome in which congenital cirrhosis or fulminant hepatitis in early infancy is associated with marked iron deposition in the liver and extrahepatic tissues..$^{1-3}$ Although the presentation of neonatal haemochromatosis with hepatic failure usually preceded by oligohydramnios, placental oedema, and intrauterine growth retardation or stillbirth is stereotypical, the cause of the condition is ill understood..$^{4-8}$ The liver is generally shrunken and bile stained with extensive fibrosis and nodular regeneration; there is massive loss of hepatocytes but surviving cells show giant cell or pseudoglandular transformation with focal nodular regeneration and varying degrees of cholestasis. Little inflammation is usually present and most of the iron deposition is found in the hepatocytes. Extrahepatic iron is seen in the acinar cells of the pancreas and minor salivary glands as well as the proximal renal tubule, adrenal cortex, thyroid, and myocardium. ${ }^{9-11}$

Although the concentration of iron in the liver is greatly increased in neonatal haemochromatosis, in rare patients who spontaneously recover and in those patients treated by orthotopic liver transplantation, the excess iron is apparently redistributed. ${ }^{12-15}$ Since increased liver iron and extrahepatic haemosiderosis may rarely result from other causes of liver disease during fetal life, ${ }^{13468}$ it has been suggested that the iron deposited in neonatal haemochromatosis may not be directly responsible for the tissue injury. ${ }^{9}$ However, in one noteworthy case, severe systemic iron overload with fatal cardiomyopathy and recurrent iron deposition in the implanted liver occurred rapidly after hepatic transplantation. ${ }^{16}$ It has been further suggested that the extrahepatic parenchymal siderosis resembles shunt siderosis in adults where reduced transferrin concentrations with increased iron transferrin saturation leads to systemic redistribution of iron; in the infant with cirrhosis a natural portocaval shunt may develop as a result of the patent ductus venosus. $^{3}{ }^{17}$

At present the diagnosis of neonatal haemochromatosis is dependent on the identification of severe liver disease of intrauterine onset associated with both hepatic and extrahepatic iron deposition that spares cells of the mononuclear phagocyte system. ${ }^{818}$ The diagnosis 
should also exclude primary structural abnormalities of the liver, internal exposure to toxins, blood group antigen incompatibility, other metabolic disorders including bile acid synthesis defects and tyrosinaemia, infection associated liver disease including cytomegalovirus (CMV), echovirus, and other agents, as well as Down's syndrome. ${ }^{19-23}$ Neonatal haemochromatosis has also been associated with birth defects ${ }^{24}$ and with distinct syndromes involving the renal tubule, hair growth, and intestinal function as well as an acidotic syndrome recently reported from Finland. ${ }^{25-27}$ Neonatal haemochromatosis has been noted in two families where it affected maternal half sibs, thus raising the possibility of causation by a maternal factor. ${ }^{28}$ Evidence for one such factor has been the description in one family of neonatal haemochromatosis as part of the neonatal lupus erythematosus syndrome associated with maternal anti-Ro/SS-A and anti-La/SS-B autoantibodies. ${ }^{29}$

About 100 cases of neonatal haemochromatosis have been reported and these show a panethnic distribution with an equal sex incidence. ${ }^{38}$ Although the syndrome may on occasion represent the common outcome of several diseases that affect the fetal liver in utero, the disorder also occurs both sporadically and recurrently in sibs in a manner that is consistent with transmission as an autosomal recessive trait. $^{2512}$ However, at present no genetic test is available to identify at risk pregnancies or provide appropriate counselling for afflicted families. An understanding of the putative genetic basis for neonatal haemochromatosis in some families would not only improve the outlook for predictive diagnosis but would provide key information as to its cause, especially in relation to the molecular physiology of iron in the fetus.

We have analysed a total of 40 infants diagnosed with neonatal haemochromatosis and who were members of 27 families. We have accordingly conducted a systematic analysis of the mode of transmission of this condition and have categorised possible patterns of inheritance; we have moreover conducted a molecular analysis of candidate genes implicated in disorders of iron metabolism.

\section{Patients}

Two index pedigrees form the nucleus of this study (fig 1).

FAMILY 1

The proband was the first child of a healthy 29 year old woman who developed hypochromic anaemia because of iron deficiency in pregnancy and received oral iron therapy. An emergency caesarian section was carried out at the onset of spontaneous labour at 36 weeks' associated with oligohydramnios. The infant had an Apgar score of 1 at one minute and 2 at 10 minutes. The infant weighed $1450 \mathrm{~g}$ ( $3 \mathrm{rd}$ centile indicating intrauterine growth retardation) and scalp bleeding and bruising was noted, as well as marked hepatomegaly. Haemoglobin was $7.5 \mathrm{~g} / \mathrm{dl}$, platelet count $79 \times 10^{9} / 1$, and she had abnormal blood coagulation. Peripheral
A (Family 1)

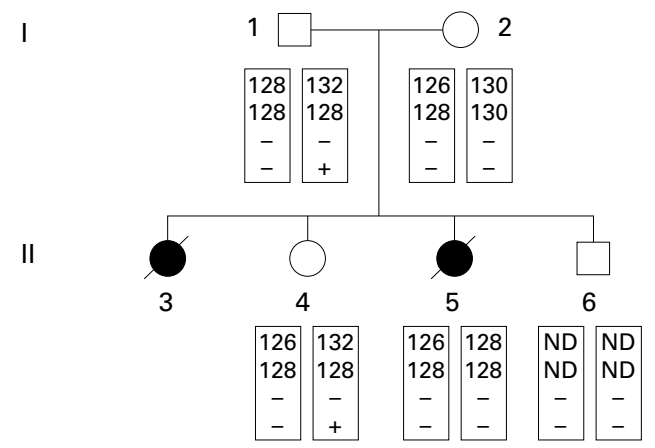

B (Family 2)

\section{I}
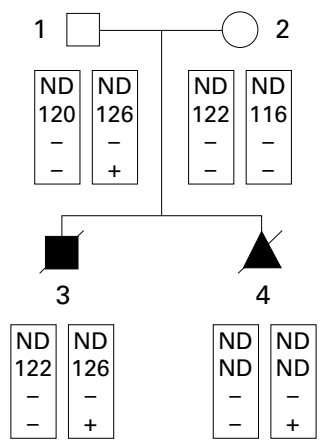

Figure 1 (A) Pedigree of index family affected by neonatal haemochromatosis. Haplotypes are displayed in the boxes, representing from top to bottom, alleles of chromosome 6 p loci in strong linkage with the HFE gene (HLA-F and D6S105) and HFE genotypes (C282Y and H63D) that are associated with adult haemochromatosis. ND indicates not done. (B) Pedigree of family with neonatal haemochromatosis showing segregation of chromosome $6 p$ marker alleles as shown in $(A)$.

oedema and anuria developed. There was little respiratory effort or spontaneous movement, hypotension occurred, and death followed at 3 days. At necropsy there was moderate jaundice and oedema with an otherwise normal external appearance. The liver had a wrinkled surface with multiple brown-purple nodules up to 1 $\mathrm{cm}$ in diameter and the spleen was enlarged. There was mesenteric haemorrhage but normal bone marrow appearances. In the lungs there was focal intra-alveolar haemorrhage and the placenta showed villus oedema. A provisional diagnosis of neonatal hepatitis with congenital cirrhosis was made. Examination of the hepatic histology showed fibrosis with cirrhosis, giant cell transformation, and hepatocellular necrosis with cholestasis and marked iron deposition in hepatocytes.

The second case in this family was the result of the third pregnancy of the mother, at that time 34 years of age. During this pregnancy and unlike those in which she gave birth to healthy infants, she again required oral iron supplements throughout pregnancy for iron deficiency anaemia (haemoglobin $<10.5 \mathrm{~g} / \mathrm{dl}$ ). The female infant was delivered by emergency caesarian section for fetal distress at 32 weeks' gestation. The Apgar score was one at 1 minute, 7 at five minutes, and 8 at 10 minutes, but the infant required ventilatory support. There was facial bruising and a widespread 

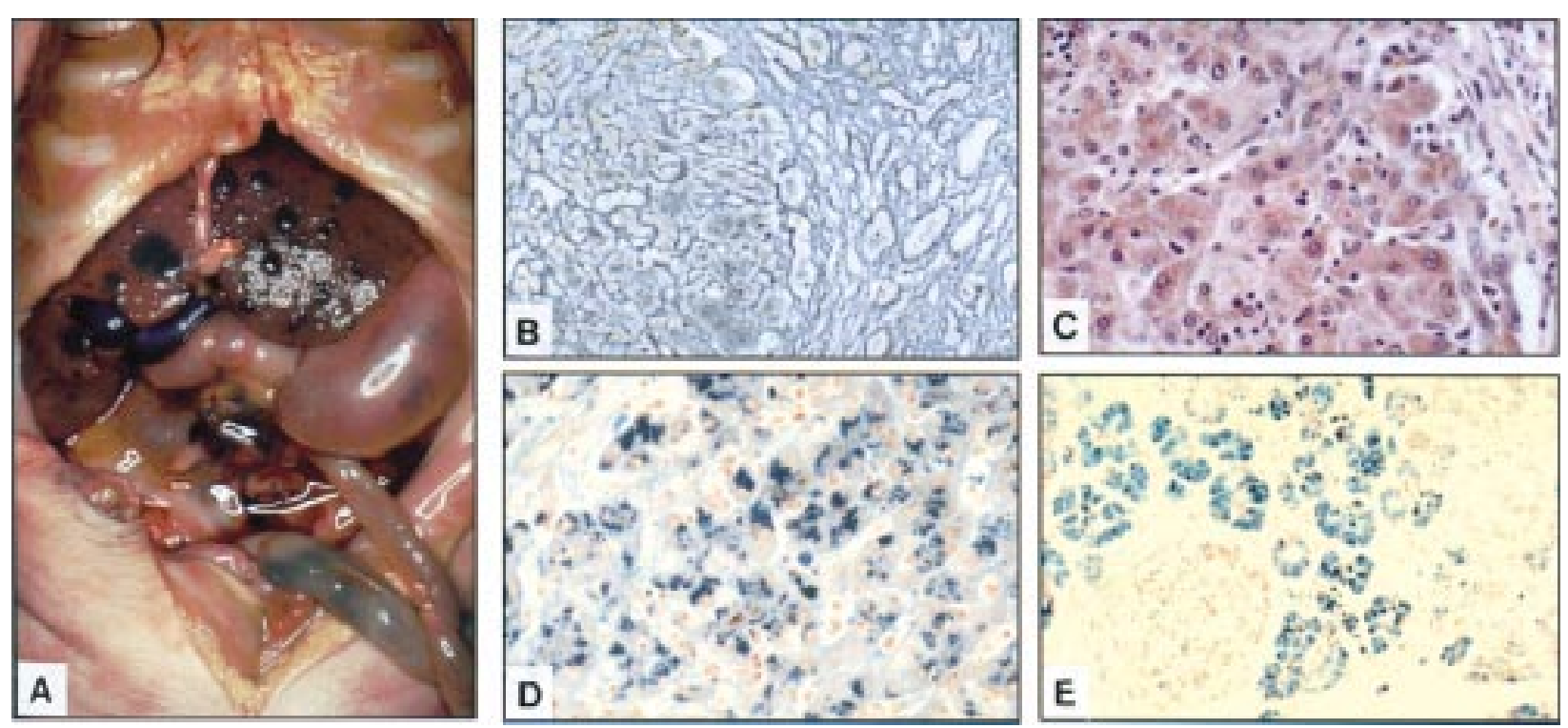

Figure 2 Pathological features in recurrent fatal neonatal haemochromatosis. (A) Macroscopic appearances of abdominal contents at necropsy showing enlarged liver with multiple dark surface nodules; generalised oedema and ascites were also present. This infant died on the sixth day of life. (B, $C$ ) Microscopic features of disrupted liver architecture showing nodule formation and pigmented and hypertrophic hepatocytes with cirrhosis (B, silver reticulin stain, $\times 100 ; C$, haematoxylin and eosin stain, $\times 400)$. (D) Liver section stained to show massive deposition of iron in hepatocytes (Perls's stain, $\times 400)$. (E) Deposition of iron in pancreatic tissue; note heavy staining of glandular acini of exocrine pancreas and also isolated punctate staining with islet cells (lower left of section) (Perls's stain, $\times 100)$.

petechial eruption. Serological tests for hepatitis A and B, acute Epstein-Barr virus infection, cytomegalovirus, and herpes simplex virus infection were negative.

The infant had a prolonged bleeding time, thrombocytopenia, a prolonged prothrombin time, and anaemia. Hypoglycaemia was also noted and she was treated with intravenous glucose and received transfusions of platelets, blood, and fresh frozen plasma. Renal failure with progressive hepatic failure occurred. Serum iron was $11.8 \mu \mathrm{mol} / \mathrm{l}$, TIBC 12.3 , and saturation $96 \%$. A normal karyotype was obtained.

In the light of the findings in the previous child, a gingival biopsy was conducted. This showed extensive iron deposition in the epithelium of minor salivary glands and a diagnosis of neonatal haemochromatosis was made. Active support was subsequently withdrawn after discussion with the parents. The infant died at 6 days of age. At necropsy the infant weighed $1944 \mathrm{~g}$ (50th centile), there was jaundice, petechial eruption, generalised oedema, and skin bruising, but otherwise normal external appearances.

The liver was shrunken and, as in the previous infant, there were multiple nodules up to $0.8 \mathrm{~cm}$ in diameter evident on the surface (fig 2A). The cut surface was reddish brown. The appearance of the bone marrow was normal. Microscopy showed oedematous placental villi and hepatic cirrhosis with marked iron excess in hepatocytes (fig 2B-D). Iron was also abundant in the exocrine pancreas (fig $2 \mathrm{E}$ ), thyroid, the zona glomerulosa of the adrenal cortex, bronchial mucous glands, renal tubules, and pulmonary macrophages.

As depicted in fig $1 \mathrm{~A}$, the parents have had four children. Their second daughter and the fourth child (a son) were healthy at birth; serum tests subsequently carried out in the parents and surviving family members showed normal transferrin iron saturation and serum ferritin determinations.

\section{FAMILY 2}

The proband was the first born male infant of a 17 year old woman of Italian origin and a Turkish father (fig 1B). Intrauterine growth retardation was noted and oligohydramnios was detected by ultrasound at 36 weeks of gestation. No atypical antibodies or rubella immunity was detected. The membranes ruptured four hours before delivery with meconium stained liquor. The infant weighed $2260 \mathrm{~g}$ (3rd centile), the crown-rump length was $49 \mathrm{~cm}$ (15th centile), and head circumference $34 \mathrm{~cm}$ (50th centile). Cord blood pH was 7.25 at birth and oedema was noted.

Shortly after delivery, hypoglycaemia was recorded and the infant was treated with intravenous glucose and four hourly enteral feeding as well as parenteral antimicrobials. By the second day of life, tachypnoea and jaundice were evident as was a metabolic acidosis. Serum bilirubin was $140 \mu \mathrm{mol} / 1$ and plasma sodium was $122 \mathrm{mmol} / \mathrm{l}$. The acidosis was treated with intravenous bicarbonate but oliguria associated with worsening jaundice and a rising serum creatinine occurred by day 3 and there was a prolonged prothrombin time. Total bilirubin rose to $168 \mu \mathrm{mol} / 1$ ( $20 \mu \mathrm{mol} / 1$ conjugated $)$ and the serum albumin decreased to $20 \mathrm{~g} / 1$. A presumptive diagnosis of herpes simplex encephalitis was made and acyclovir was administered. A diagnosis of hepatorenal failure in relation to a possible metabolic disorder was also considered.

The patient was noted to have an enlarged liver and spleen but on the fourth day of life developed a massive haematemesis and melaena requiring exchange blood transfusions 


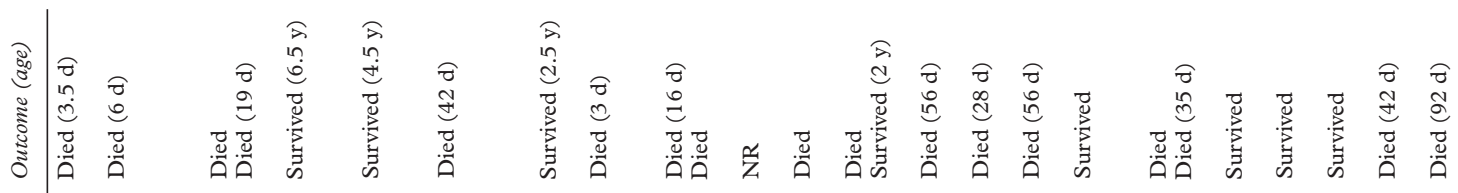

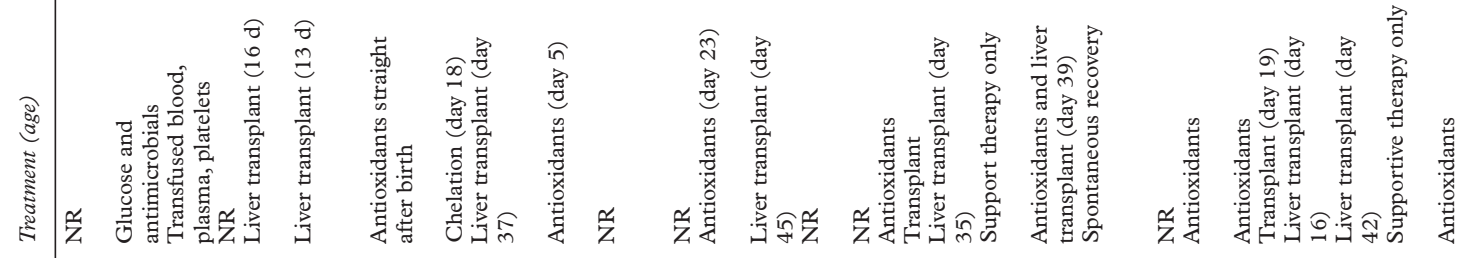

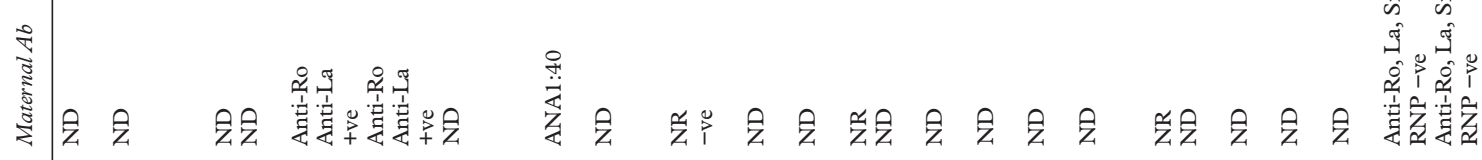

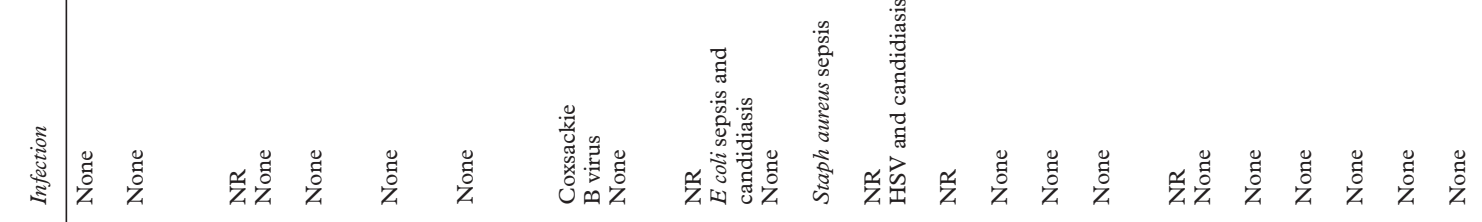
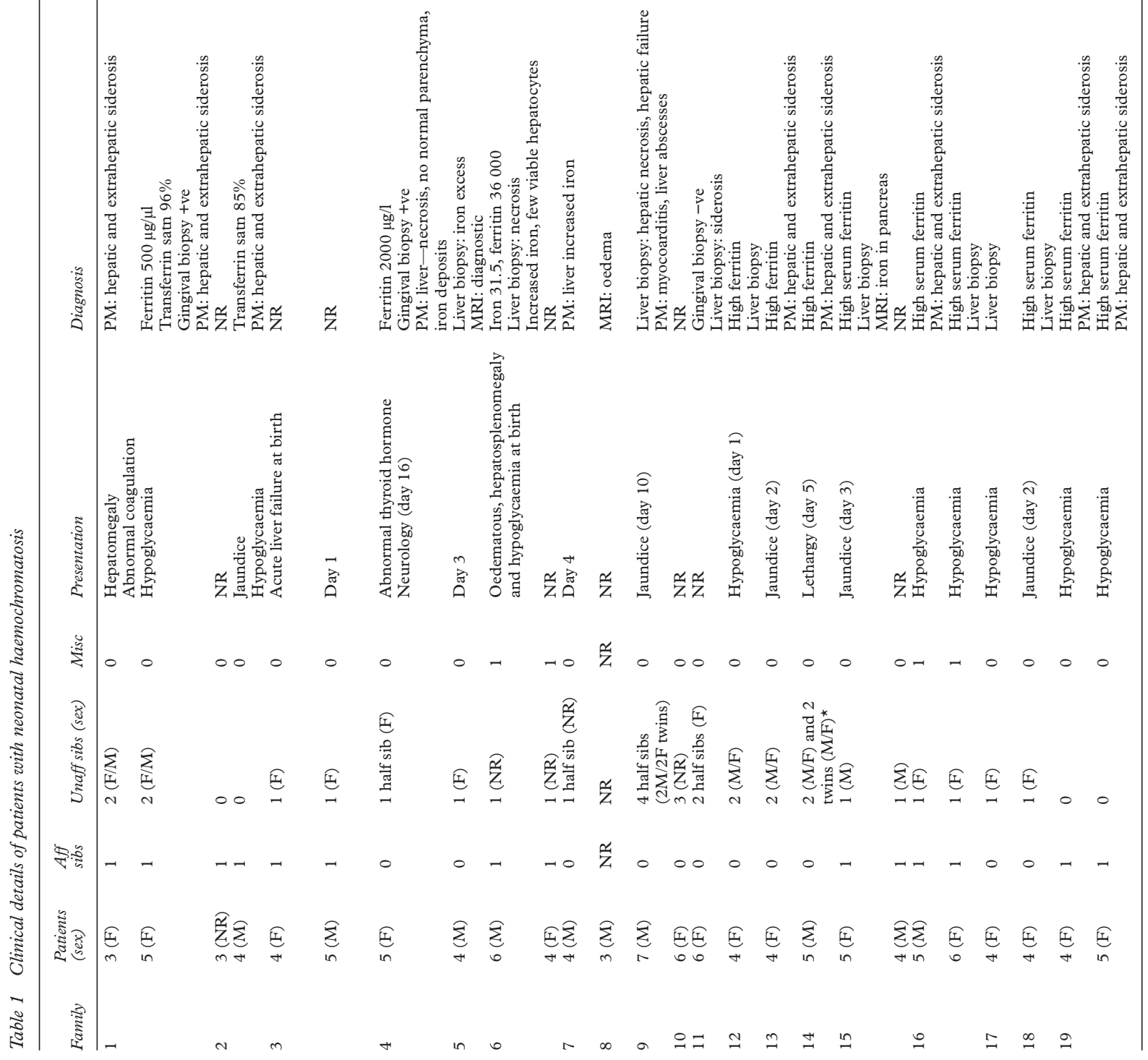


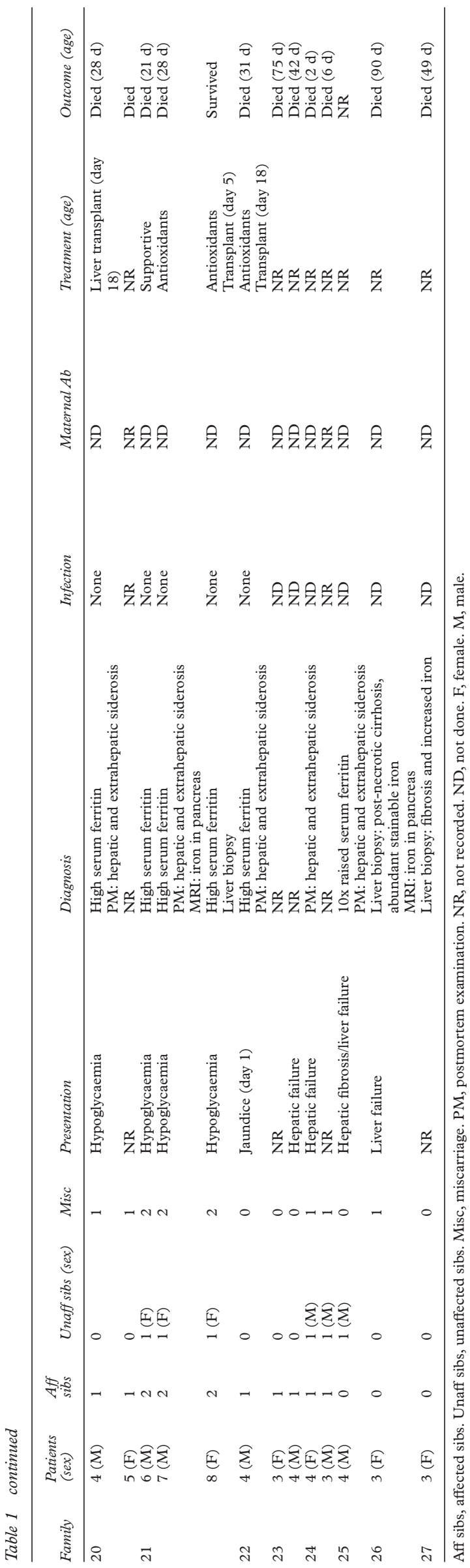

and albumin infusions together with intravenous glucose. Ultrasound examination showed a shrunken liver with normal bile ducts and extensive ascites, with a patent portal vein. Serological investigation showed negative HIV 1 and hepatitis serology, a negative direct Coomb's test, normal G6PD activity, and a normal bone marrow (showing reactive changes only). Urine succinyl acetone was not detected, thus excluding hereditary tyrosinaemia. The activity of enzymes for galactosaemia was normal and $\alpha_{1}$-antitrypsin phenotyping was normal. Serological tests for toxoplasma, herpes simplex, and CMV titres were negative. Hyperammonaemia was shown together with progressive renal failure and prolonged blood coagulation parameters. The infant was transferred to Addenbrooke's Hospital for hepatic transplantation. Further tests showed no reducing substances in the urine but generalised raised plasma amino acids compatible with hepatic failure. Orthotopic transplantation of the liver was carried out from a 3 year old donor but the patient suffered the consequences of hepatic arterial thrombosis in relation to difficult anastomotic procedures and died on the 19th day of life.

At necropsy, the child was oedematous with extensive bruising; the explanted liver weighed $43 \mathrm{~g}$ and showed widespread nodules and bile staining with evidence of regeneration. Microscopy showed vacuolated hepatocytes, giant cell transformation, metaplastic bile ductules with bile plugs, and widespread haemosiderin in hepatocytes and ductular cells with a small amount of fibrosis.

Extensive iron deposits were also identified in the myocardium, acinar cells of the pancreas, gastric crypts, tracheal and bronchial glands, proximal renal tubules, adrenal cortex, thymus, thyroid, and salivary glands, as well as pulmonary alveolar macrophages. No excess iron was identified in the spleen, testes, or bone marrow. On the basis of these findings, a diagnosis of neonatal haemochromatosis was made. Subsequently the mother had another pregnancy which terminated in a spontaneous abortion at 30 weeks of gestation with an infant with growth retardation, jaundice, and other signs of neonatal hepatitis.

A further 20 families (3-22) were recruited from paediatric liver units in the United Kingdom in a nationwide collaborative study (table 1). Also included in this study were established fibroblast cell lines representing five families (23-27) from Corriell Cell Repositories, Camden, New Jersey. Twenty-two families are from referral centres within the United Kingdom. Examining information supplied about all 27 affected pedigrees with a total of 68 children, 40 have been diagnosed as having neonatal haemochromatosis. The male to female ratio of these neonatal haemochromatosis patients (16:24) does not strictly follow the $1: 1$ ratio previously reported but is not significantly different from that expected to arise by chance $\left(\chi^{2}=2.67,1 \mathrm{df}, \mathrm{p}>0.05\right)$. In the 28 unaffected children, there is a slight but statistically insignificant bias towards females rather than males (8:14), but at the time of writing the gender of 
A
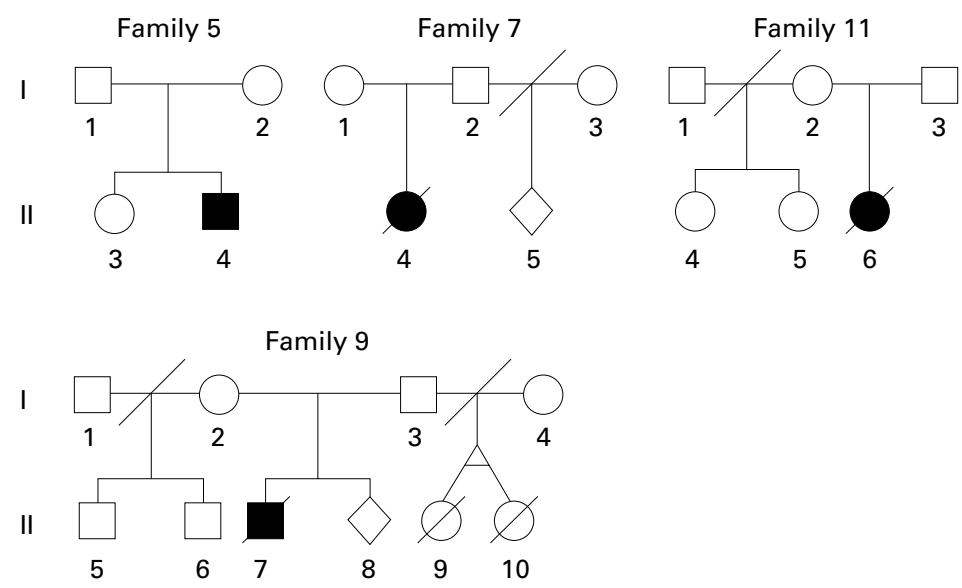

B
Family 3

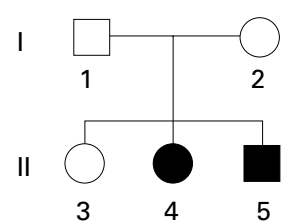

Family 19

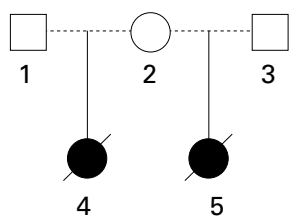

Family 20

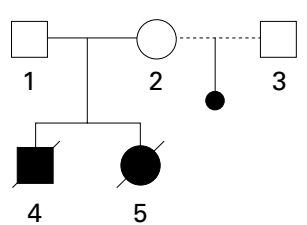

Figure 3 Patterns of disease transmission in pedigrees affected by neonatal haemochromatosis. (A) Neonatal haemochromatosis associated with maternal infections. (B) Neonatal haemochromatosis acquired as a result of (non-infectious) maternal factor(s).

six children is not available. Thirty of the 40 neonatal haemochromatosis patients have died, four of whom had undergone hepatic transplantation. A further six patients survived after orthotopic liver transplantation and are currently making good progress without evidence of continuing tissue injury or organ failure. Four neonatal haemochromatosis patients did not receive hepatic transplantation but made a spontaneous recovery and remain well.

These patients were diagnosed principally on the basis of liver biopsy and for that reason could not meet the strict criteria required for showing extrahepatic iron deposits; they are however included in this study for completeness.

It was evident early in the course of this study that neonatal haemochromatosis indeed affects multiple subjects within given sibships. However, further scrutiny of the affected pedigrees showed three clear patterns of disease transmission. These are shown in the additional pedigrees (fig 3).

(1) Neonatal haemochromatosis transmitted as a result of maternal disease (infection) acquired during pregnancy (fig 3A). In family 5, infection was Coxsackie viral infection; in family 7 the infection was $E$ coli bacteraemia and candidiasis; in family 9 it was Staphylococcus aureus; and in family 11 it was Herpes simplex virus and candidiasis. In the affected infants of these families, excess iron was found only in the liver.

(2) Neonatal haemochromatosis acquired as a result of a maternal factor (fig 3B).
(3) Neonatal haemochromatosis transmitted in a manner compatible with or indicating an autosomal recessive trait (fig 3C).

\section{Methods}

gDNA STUDIES

Genomic DNA was isolated from 3-5 $\mathrm{ml}$ of peripheral blood from families 1-22, two healthy controls, and from established fibroblasts cell lines of families $23-27 .{ }^{30}$

\section{CDNA STUDIES}

Peripheral blood mononuclear cells were isolated from venous blood using Ficoll-paque (Amersham, Pharmacia Biotech) density gradient centrifugation from all members of family 1 except subject 3 where fibroblasts were used and one control sample. Total RNA isolation from these leucocytes was carried out using Trizol reagent (Life Technologies). First strand cDNA was then synthesised using the Pro Star ${ }^{\text {TM }}$ RT-PCR kit (Stratagene).

DNA SEQUENCING: HFE GENE

To analyse the complete $H F E$ gene in families 1 and 2 and in two healthy controls, oligonucleotide primers were designed from the human $H F E$ genomic sequence (Gene Bank accession no Z92910) and used to amplify genomic DNA sequences. Purification of amplified PCR products and direct automated sequencing was carried out as described previously. ${ }^{30}$

CLASS I MHC AND RELATED GENOTYPING

MHC class I genotypes for the HLA-F locus and additional genotyping at the D6S105 locus telomeric to the class I region on chromosome $6 \mathrm{p}$ but showing strong linkage association with adult haemochromatosis was carried out as previously described. ${ }^{31}$

$\beta_{2}$-MICROGLOBULIN GENE

The $\beta_{2}$-microglobulin gene was fully sequenced in families 1 and 2, as well as two healthy controls, using primers and PCR conditions previously described and using genomic DNA as a template. $^{32}$

\section{HAEM OXYGENASE GENES}

Haem oxygenase 1 (HMOX1)

This gene was amplified from genomic DNA isolated from members of families 1 and 2, affected subjects only from families 23 to 25, and two normal subjects, as two long range PCR products using the Expand ${ }^{\mathrm{TM}}$ Long Template PCR system (Boehringer Mannheim). Two pairs of primers were designed from the human H01 sequence (Gene Bank accession No XO6985) to amplify the two long range PCR products and are as follows: HMOX1-1, agcgtc ctcagcgcagccgc; HMOX1-4, ctgactcgggagt catctcca; HMOX1-2, catggccctgggagccagcat; and HMOX1-3, agaagagctgcaccgcaaggc. Amplification was carried out according to the manufacturers' instructions which included two rounds of amplification and elongation in the second cycle increased by 20 seconds per cycle. The long range PCR products were purified using an equal volume of $6 \%$ polyethylene glycol 
C

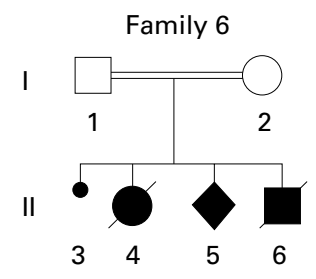

Family 13

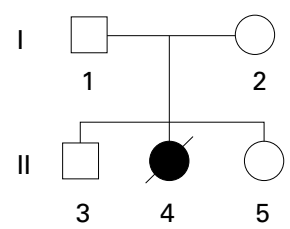

Family 12

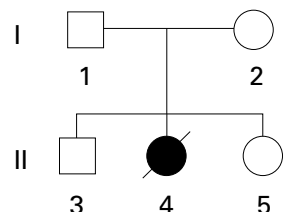

Family 21

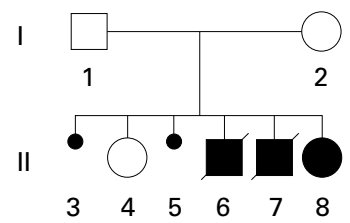

Family 14

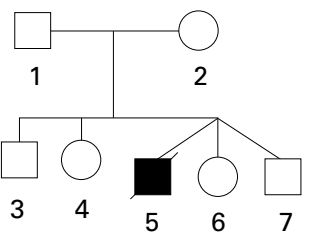

Family 16

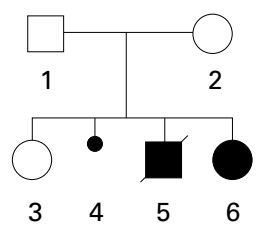

Family 17

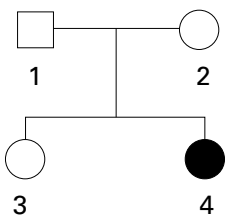

Family 22

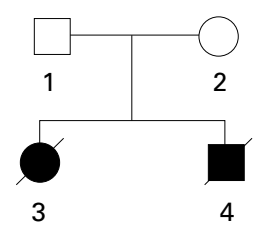

Family 10

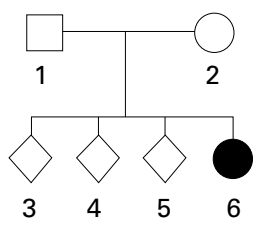

Family 15

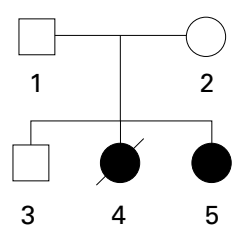

Family 18

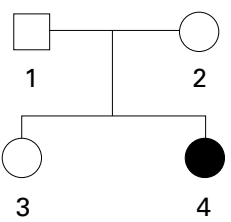

Family 4

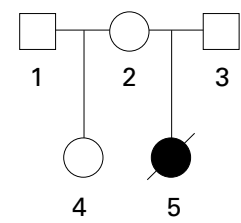

Figure 3 (C) Neonatal haemochromatosis transmitted as a putative autosomal recessive trait.

8000 solution at room temperature for $20 \mathrm{~min}$ utes followed by bench centrifugation at 13000 $\times g$ for 30 minutes. After the supernatant had been removed, the pellet was washed twice with cold $70 \%$ ethanol and washed by centrifugation for 20 minutes. The pellet was then allowed to dry in air before being resuspended in sterile distilled water and used as a DNA template for automated sequencing. The above primers (HMO1X-1 and HMOX1-4) and an additional seven primers (HMOX1-5-11) were used to ensure that the sequences included all five exons, spliced sites, and lariat spliced junction regions of the HMOX1 gene. The sequences of HMOX1 primers 5-11 are as follows: HMOX1-5 ggcagagaatgctgagttcatg; HMOX1-6 aagccgtctcgggtcacctg; HMOX1-7 ttgaggagtt gcaggagctg; HMOX1-8 tccttggtgcatgggtcag; HMOX1-9 acaccegtacctgggtgac; HMOX1-10

Table 2 Restriction endonuclease digestion confirming base substitutions in the HFE gene

\begin{tabular}{|c|c|c|c|c|}
\hline Polymorphism & Restriction enzyme & $\begin{array}{l}\text { Restriction enzyme } \\
\text { site }\end{array}$ & $\begin{array}{l}\text { Restriction site } \\
\text { Wild type }\end{array}$ & $\begin{array}{l}\text { Restriction site } \\
\text { Base change }\end{array}$ \\
\hline $\mathrm{G} \rightarrow \mathrm{A} \mathrm{C} 282 \mathrm{Y}$ & $R s a \mathrm{I}$ & $\begin{array}{l}G \mathrm{~T} \boldsymbol{\nabla}_{\mathrm{AC}} \\
C_{\mathrm{A}} \boldsymbol{\Delta}_{\mathrm{TG}}\end{array}$ & Absent & Present \\
\hline $\mathrm{C} \rightarrow \mathrm{G} \mathrm{H63D}$ & $B c l I$ & $\begin{array}{l}\mathrm{T} \boldsymbol{\nabla} \mathrm{GAT} C \mathrm{~A} \\
\mathrm{ACTA} G \boldsymbol{\Delta}_{\mathrm{T}}\end{array}$ & Present & Absent \\
\hline $\mathrm{A} \rightarrow \mathrm{T}$ S65C & $\operatorname{HinfI}$ & $\begin{array}{l}\mathrm{G} \boldsymbol{\nabla} A_{\mathrm{NTC}} \\
\mathrm{C} T_{\mathrm{NA}} \boldsymbol{\Delta}_{\mathrm{G}}\end{array}$ & Present & Absent \\
\hline $\mathrm{T} \rightarrow \mathrm{C} 4 \mathrm{~T} \rightarrow \mathrm{C}$ & $R s a \mathrm{I}$ & $\begin{array}{l}G \mathrm{~T} \boldsymbol{\nabla C} \\
C_{\mathrm{A}} \mathbf{\Delta}_{\mathrm{TG}}\end{array}$ & Absent & Present \\
\hline $\mathrm{T} \rightarrow \mathrm{C} 116 \mathrm{~T} \rightarrow \mathrm{C}$ & Sau $96 \mathrm{I}$ & $\begin{array}{l}\mathrm{G} \boldsymbol{\nabla}_{\mathrm{G}} N_{\mathrm{CC}} \\
\mathrm{CC} N_{\mathrm{G}} \boldsymbol{\Lambda}_{\mathrm{G}}\end{array}$ & Absent & Present \\
\hline
\end{tabular}

catgcccaggatttgtcag; and HMOX1-11 gtcac ccaggtagcgggtgt.

Haem oxygenase 2 (HMOX2)

A pair of primers, HMOX2-A, tgactggagget ggcggaca and HMOX2-B, ttagtcagggctgga gaaag, were designed from the human $\mathrm{HO} 2$ mRNA sequence (Gene Bank Accession No S34389) to amplify the full length HMOX-2 cDNA. Complementary cDNA was isolated from peripheral blood monocytes from members of family 1 and a healthy control. RT-PCR was carried out using $5 \mu$ of template cDNA from all members of family 1 . An annealing temperature of $58^{\circ} \mathrm{C}$ was used with a total of 35 cycles. One $\mu \mathrm{l}$ of the amplified RT-PCR product was then used as a template in a nested PCR reaction using two sets of primers, HMOX2-A and HMOX2-C, cacattctcaaacatg and HMOX2-B and HMOX2-D, tctacctgtttga gaatgtg, resulting in two products encompassing the full length HMOX2 cDNA sequence. The nested PCR products were purified and sequenced directly as described for the $H F E$ gene. $^{30}$

CONFIRMATION OF BASE CHANGES

The base changes from the wild type (Wt) sequence identified in the HFE gene were confirmed by restriction enzyme digestion for sites that either created or removed a recognition sequence for a restriction endonuclease (table $2)$. The base differences identified in the $H M O X 1$ gene were confirmed by sequencing the opposite strand using the primers G425Ar (tggcatcttggcatgtcgcct), A198Gf (tacagctcagacctaattgc), and A226Gr (ttgccagtgagctgagatcg).

\section{Results}

From the information obtained from 27 families afflicted by neonatal haemochromatosis (table 1 , figs $1 \mathrm{~A}, \mathrm{~B}$ and $3 \mathrm{~A}, \mathrm{~B}, \mathrm{C}$ ), 12 had more than one affected infant. In five of these 12 families (Nos 2, 19, 20, 22, and 23) all the infants born were affected by neonatal haemochromatosis; in the remaining seven families (Nos 1, 3, 6, 15, 16, 21, and 24) children not affected by the disease were also born.

In relation to birth order, in three of these seven families (Nos 1, 6, and 24), unaffected offspring born to the same parents either alternated with or followed infants affected by neonatal haemochromatosis. In the remaining four families (Nos 3, 15, 16, and 21), it was the first born child of the parents who was unaffected; in these families the healthy child was followed by the birth of two or more affected sibs.

In 15 out of the total of 27 families, only one child was affected by neonatal haemochromatosis; in three (Nos 8, 26, and 27) no more children were born, leaving a residue of 12 families (Nos 4, 5, 7, 9-14, 17, 18, and 25) who had also had offspring unaffected by the disease. 
MODE OF DISEASE TRANSMISSION

Infection acquired in pregnancy

In four families there was clear evidence of perinatal infection associated with haemochromatosis (families 5, 7, 9, and 11) in which Coxsackie B virus, bacterial sepsis with $E$ coli and $S$ aureus, and Herpes simplex virus (HSV) type 1 infections, respectively, were associated with the disease. All had a single affected infant and one or more unaffected sibs or half sibs. In family 5, a male infant (second born) presented with liver failure at 3 days of age. The diagnosis was confirmed on liver biopsy and increased iron deposition was identified by magnetic resonance imaging (MRI) of the abdomen. Acute Coxsackie B virus infection was shown serologically in the mother and the infant was treated with an antioxidant cocktail leading to a resolution of the symptoms with survival of this male child for at least $21 / 2$ years at the time of writing. It is not possible to determine whether in family 5 extrahepatic iron deposits were present; in family 7 and family 8 necropsy showed extensive hepatic iron deposits only. In family 11 , a gingival biopsy was conducted and no increased iron was detected; liver biopsy showed hepatic iron deposits in this infant who recovered. Affected patients in all four pedigrees presented within the first 10 days of birth.

In family 7 , a female infant who subsequently had an unaffected paternal half sib presented with liver failure at the age of 4 days. $E$ coli sepsis was found together with candidiasis on blood cultures. Antibody tests showed no evidence of maternal ribonuclear protein antibodies or antinuclear factor and the infant was treated with an antioxidant cocktail but died. Necropsy showed the typical features of neonatal haemochromatosis with greatly increased iron deposition in the liver. Staphylococcal sepsis occurred in the mother of family 9 and the infant died within two weeks of birth with fulminant hepatitis and septicaemia complicated by myocarditis and liver abscess formation.

In family 11 , where there are two unaffected older maternal half sibs, the index case presented with fulminant hepatic failure. There was serological evidence of an acute Herpes simplex virus infection in the mother. Siderosis and neonatal hepatitis were diagnosed on liver biopsy and the patient was treated initially with an antioxidant cocktail. ${ }^{33}$ She failed to improve and later an orthotopic liver transplant was carried out from which she has made a good recovery and is now alive two years later. A diagnosis of neonatal haemochromatosis was confirmed by examination of the explanted liver.

Maternal transmission of disease

We have observed two distinct patterns of disease transmission in neonatal haemochromatosis that suggest the influence of a maternal factor. In family 3, with the second and third born affected, in a sibship of three there was clear evidence of maternal antibodies to ribonuclear proteins; anti-Ro and anti-La antibodies were also detected in the affected infants. The association of full blown neonatal haemochromatosis with the appearance of maternal antinuclear factor and ribonuclear antibodies has been reported, ${ }^{29}$ but the presence of antibody in plasma from the affected infants appears not to be obligatory. The occurrence of neonatal haemochromatosis in the context of maternal antibodies may indicate a favourable outcome, since in the two infants reported here in family 3 both have survived $41 / 2$ and 6 years after diagnosis and remain in good health. In this particular family, one infant received an hepatic allograft but the other responded to treatment with antioxidants. ${ }^{33}$

In the remaining subgroup, neonatal haemochromatosis has appeared in offspring of either sex who are maternal half sibs (that is, families 19 and 20). The occurrence of disease in half sibs has been previously noted, ${ }^{28}$ although in these instances the presence of maternal antinuclear or ribonuclear protein antibodies was not formally excluded. Clearly in these instances, the occurrence of disease could also result from either maternal transmission of mitochondria harbouring pathogenic mutations in the organellar genome, or from gonadal mosaicism for a new dominant gene mutation in the mother. Evidence for the possibility of gonadal mosaicism might be suggested in one family (family 9) in which twin half sibs who died of unknown causes may have been affected by neonatal haemochromatosis; these sibs were paternal rather than maternal half sibs.

Clearly, if maternal transmission of neonatal haemochromatosis either as an acquired trait or as a result of mitochondrial mutations is a possibility, this has profound implications for genetic counselling. In at least two instances in the series reported here, mothers who had borne children affected by the disease had had further affected pregnancies as a result of insemination from sperm donors, which had been arranged after genetic counselling on the mistaken assumption of the operation of recessive inheritance in all cases of neonatal haemochromatosis.

\section{Transmission suggesting autosomal recessive} inheritance

As noted above, in 15 of the 27 families only one child was affected by neonatal haemochromatosis; in three of 15 (families 8, 26, and 27) no further children were born. Thus in 12 families (Nos 4,5, 7, 9-14, 17, 18, and 25) unaffected children were also born. Owing to uncertainties of ascertainment, it is of limited value to estimate recurrence figures for the sibships as a whole or afterborn sibs alone. However, based on the 13 families with full sibships of two or more, in which there was no evidence of infection, maternal antibody, maternal transmission, or mosaicism (families 1, 2, 6, 10, $12-18,21-25)$, there were 18 full sibs born after the proband; this includes two unaffected sibs in the multiple births that occurred in family 14. Of these, 10 of the 18 were affected by neonatal haemochromatosis, which, even allowing for exaggerated ascertainment bias, exceeds the expected (approximately four) affected sibs 
Table 3 HFE genotypes for families 1 and 2 and affected patients from families 23, 24, 25 , and 27

\begin{tabular}{lllllll}
\hline & & Exon 4 & Exon 2 & Exon 2 & Intron 2 & Intron 4 \\
Family & Subject & C282Y & H63D & S65C & $4 T \rightarrow C$ & $116 T \rightarrow C$ \\
\hline 1 & 1 (father) & $-/-$ & $+/-$ & $-/-$ & $+/-$ & $-/-$ \\
1 & 2 (mother) & $-/-$ & $-/-$ & $+/-$ & $+/-$ & $+/-$ \\
1 & 4 (unaffected) & $-/-$ & $+/-$ & $+/-$ & $+/+$ & $+/-$ \\
1 & 5 (affected) & $-/-$ & $-/-$ & $+/-$ & $+/-$ & $+/-$ \\
1 & 6 (unaffected) & $-/-$ & $-/-$ & $-/-$ & $-/-$ & $-/-$ \\
2 & 1 (father) & $-/-$ & $+/-$ & $-/-$ & $+/-$ & $-/-$ \\
2 & 2 (mother) & $-/-$ & $-/-$ & $-/-$ & $-/-$ & $-/-$ \\
2 & 3 (affected) & $-/-$ & $+/-$ & $-/-$ & $+/-$ & $-/-$ \\
2 & 4 (affected) & $-/-$ & $+/-$ & $-/-$ & $+/-$ & $-/-$ \\
23 & 3 (affected) & $-/-$ & $+/+$ & $-/-$ & $-/-$ & $-/-$ \\
23 & 4 (affected) & $-/-$ & $+/+$ & $-/-$ & $-/-$ & $-/-$ \\
24 & 4 (affected) & $-/-$ & $+/+$ & $-/-$ & $-/-$ & $-/-$ \\
25 & 4 (affected) & $-/-$ & $+/-$ & $-/-$ & $+/-$ & $-/-$ \\
27 & 3 (affected) & $-/-$ & $+/+$ & $-/-$ & $-/-$ & $-/-$ \\
\hline
\end{tabular}

predicted for the 1 in 4 recurrence risk associated with inheritance of an autosomal recessive trait. However, since it may be assumed that the likelihood of ascertainment of any given sibship is proportional to the number of affected sibs, ${ }^{34}$ then by excluding the proband the ratio of affected to unaffected sibs can be calculated as the segregation ratio. In this instance, for pedigrees $1,2,6,10,12-18$, 21-25, and excluding stillbirths, there were 11 affected sibs and 20 unaffected sibs observed which is not significantly different from the expected 7.75 affected sibs out of the total of 31. The trend of this proportion is thus to be found biased in the expected direction of ascertainment with respect to the present study of multiply affected sibships, in which ascertainment would be expected to be enhanced over the likelihood of identifying haemochromatosis in sibs where this was proportional simply to the number of sibs affected.

Consanguinity was observed in only one family (family 6) which was of Asian descent but produced all four offspring affected (one stillbirth, three neonatal deaths). Investigations showed no evidence of infection and a normal bile acid profile. However, among 27 families, one consanguineous family of Asian descent would not be exceptional and cannot alone be regarded as decisive evidence of inheritance of an autosomal recessive trait. Similarly, although recessive inheritance could provide an alternative explanation for the affected paternal half sibs in family 9, this would require both mothers to be heterozygous carriers which would be exceptional, unless they were in fact related by blood.

In another family (family 14), one male infant of five children born to the parents was affected by neonatal haemochromatosis. This infant was one of non-identical triplets and died at 57 days after having undergone two orthotopic liver transplant procedures; in this instance, transplantation surgery was undertaken after the administration of the parenteral antioxidants had proved to be unsuccessful. In family 15 , one infant died and one recovered without the benefit of transplantation. We do not consider that this excludes a genetic trait which could predispose to disease under conditions of extreme stress, for example, during the neonatal period when haemolysis is most active. The occurrence of disease in only one of three non-identical newborn triplets provides little support for mitochondrial inheritance or for the operation of other maternal factors including infection in this family, but clearly cannot formally exclude de novo mutation.

Overall it is clear that acquisition of neonatal haemochromatosis as a result of maternal transmission, mitochondrial inheritance, de novo dominant mutation but with a significant chance of gonadal mosaicism all need consideration in any given pedigree, especially where genetic counselling is being sought. However, it can be seen that in an important subgroup of families affected by neonatal haemochromatosis, inheritance of an autosomal recessive trait cannot be excluded.

\section{DIRECT SEQUENCE ANALYSIS OF CANDIDATE} GENES

\section{HFE gene}

The principal mutation, $\mathrm{C} 282 \mathrm{Y}$, in the $H F E$ gene responsible for adult haemochromatosis was not present in any of the six families examined by direct sequencing and/or restriction endonuclease digestion (table 3). However, the H63D mutation segregated in families 1,2 , and 25 but not in association with neonatal haemochromatosis, since only the father and first unaffected child in family 1 carried a single copy of H63D. The frequency of the H63D allele of $H F E$ in the European population is about $0.25^{34}$ with a predicted frequency of homozygotes of about 0.02 . The $193 \mathrm{~A} \rightarrow \mathrm{T}$ substitution in the second exon of the $H F E$ gene, which leads to the S65C substitution ${ }^{35}$ that has been shown to be associated with a mild form of adult haemochromatosis, only segregated in family 1 and was not present in $108 \mathrm{HFE}$ alleles from 54 control samples. Complete sequencing of the $H F E$ gene in families 1 and 2 identified two intronic base changes, intron $24 \mathrm{~T} \rightarrow \mathrm{C}$ and intron 4 $116 \mathrm{~T} \rightarrow \mathrm{C},{ }^{36}{ }^{37}$ the allele frequencies being $48 \%$ and $19 \%$, respectively. Thus, no additional causative mutations were identified in any of the eight subjects affected by neonatal haemochromatosis that we examined.

\section{$\beta_{2}$-microglobulin gene}

Complete sequencing of the $\beta_{2}$-microglobulin gene in families 1 and 2 identified differences from the published sequence (gene bank M17986) in exon 1 (absence of G837 and CCT in place of GGC at nucleotides 940942), exon 2 (substitution of $\mathrm{A}$ for a $\mathrm{C}$ at nucleotides 107, gene bank M17987, and the absence of a previously reported base change at nucleotide $200^{31}$ ) and intron 1 (an additional c after nucleotide 989 and an additional 21 base pairs). This latter additional base change $989+\mathrm{C}$ in intron 1 and codon substitution Q70P $(210 \mathrm{C} \rightarrow \mathrm{A})$ in exon 2 were not observed in families 1 and $2 .^{32}$ In the two families investigated, the remaining $\beta_{2}$-microglobulin coding sequence and splice sites corresponded to the 
Table 4 HMOX1 genotypes for families 1 and 2 and affected subjects from families 23-25

\begin{tabular}{|c|c|c|c|c|c|}
\hline Family & Subject & $\begin{array}{l}\text { Intron } 1 \\
425 G \rightarrow A\end{array}$ & $\begin{array}{l}\text { Intron } 4 \\
198 A \rightarrow G\end{array}$ & $\begin{array}{l}\text { Intron } 4 \\
226 A \rightarrow G\end{array}$ & $\begin{array}{l}\text { Intron } 3 \\
\text { frameshift, } T \\
\text { base } 194\end{array}$ \\
\hline 1 & 1 (father) & $+/-$ & $-/-$ & $+/-$ & Present \\
\hline 1 & 2 (mother) & $-/-$ & $-1-$ & $-1-$ & $\mathrm{Wt}$ \\
\hline 1 & 4 (unaffected) & $+/-$ & $+/-$ & $+/-$ & Present \\
\hline 1 & 5 (affected) & $-1-$ & $-1-$ & $-1-$ & $\mathrm{Wt}$ \\
\hline 1 & 6 (unaffected) & $+/-$ & $+/-$ & $-1-$ & Present \\
\hline 2 & 1 (father) & $-/-$ & $-1-$ & $-/-$ & Wt \\
\hline 2 & 2 (mother) & ND & $+1-$ & $-1-$ & Present \\
\hline 2 & 3 (affected) & ND & $+/-$ & $+/-$ & Present \\
\hline 2 & 4 (affected) & $-1-$ & $-1-$ & $-1-$ & Wt \\
\hline 23 & 3 (affected) & $-/-$ & $+/+$ & $-1-$ & Present \\
\hline 23 & 4 (affected) & $-/-$ & $+/+$ & $-1-$ & Present \\
\hline 24 & 4 (affected) & $-/-$ & $+/+$ & $-1-$ & Present \\
\hline 25 & 4 (affected) & $-/-$ & $+/-$ & $-1-$ & Present \\
\hline
\end{tabular}

wild type sequence and we believe that the differences in intronic and exonic sequences reported here are likely to be innocuous and thus of little relevance to the pathology of neonatal haemochromatosis.

Haem oxygenase 1 gene (HMOX1)

The HMOX1 gene was sequenced in its entirety for all members of families 1 and 2 and the affected neonatal haemochromatosis patients from families 23 to 25 . No base substitutions were identified in the five exonic sequences of $H M O X 1$; however, three nucleotide changes were found in the intronic sequences: intron $1 \mathrm{G} \rightarrow \mathrm{A}$ at nucleotide 42 and $\mathrm{A} \rightarrow \mathrm{G}$ at nucleotides 198 and 226 in intron 4. Additionally, a frameshift was found in intron 3, an extra $t$ at nucleotide 198 from the intron/exon boundary of exon 4, followed by a repeated sequence (ccttcctt) which ensured no alteration in the exon 4 sequence (table 4 ).

Haem oxygenase 2 gene (HMOX2)

Complete sequencing of the $H M O X 2 \mathrm{cDNA}$ in family 1 showed no base substitutions in the coding sequence. Complementary cDNA analysis provided no information on the flanking intron/exon sequences. However, on the nature of the intron/exon boundaries no splice variants were identified.

\section{Discussion}

Criteria for the diagnosis of neonatal haemochromatosis have emerged only recently. The condition is defined as a rapidly progressive disorder with death in utero or in the early neonatal period, with increased tissue iron deposits seen in the liver, pancreas, heart, and endocrine glands, but with relative sparing of extrahepatic mononuclear phagocytes. The diagnosis can only be considered in the absence of haemolytic disease or other syndromes associated with haemosiderosis or exogenous iron overload from transfusions. ${ }^{3} 489$

Neonatal haemochromatosis occurs as a part of neonatal lupus erythematosus syndrome associated with maternal anti-Ro/SS-A and anti-Ro/SS-B autoantibodies. ${ }^{29}$ In this previous single case report, full blown neonatal haemochromatosis in which the criteria for extrahepatic iron deposition were met was associated with the maternal autoantibodies that were identified in the patients depicted in fig $3 \mathrm{~B}$. Increased deposition of hepatic iron (hepatic "siderosis") has also been associated with genetic defects of bile acid synthesis, hereditary tyrosinaemia, Zellweger syndrome, and leprechaunism. ${ }^{8}$ Hepatic pathology is accompanied by a bleeding diathesis, hypoglycaemia, metabolic acidosis, and incipient renal failure and it seems likely that the giant cell hepatitis that characterises the condition in the presence or absence of defined viral infection in the mother is the end result of multiple insults.

We review here pedigree studies of a large series of patients and the molecular analysis of candidate genes implicated in iron metabolism. This includes genes expressed in the human placenta which were studied because the mother represents the only source of additional iron before birth. However, although MRI imaging and chemical analysis of tissue iron concentrations indicate that neonatal haemochromatosis is indeed associated with excess iron in liver tissue ${ }^{48}$ and its redistribution to extrahepatic tissues, ${ }^{389}$ it is by no means clear that all patients with neonatal haemochromatosis harbour an increase in total body iron. In those patients who recovered from the condition either as a result of, or despite administration of antioxidant therapy or successful orthotopic hepatic transplantation, the majority show no evidence of disordered iron metabolism. Moreover, no other iron storage diseases are found in the parents or surviving sibs of affected subjects. ${ }^{13-15} 3940$

The degree of iron overload in patients with haemochromatosis may be sufficient to induce (as with the adult disease) malignant tumours and there are three published reports in which primary hepatocellular carcinomas have occurred in neonatal haemochromatosis. ${ }^{3}$ It is of great interest that in one of these patients, further iron accumulated in the donor liver and in an amount comparable to that present in the explanted organ: the recipient eventually died as a result of a cardiac arrythmia associated with marked cardiac siderosis and cardiomyopathy. ${ }^{16}$ In this patient at least, an iron loading disorder was present in utero and after birth that presumably affected transplacental and possibly also intestinal transport of iron.

Of particular note in the present series of patients is the evidence for a substantial subgroup in which the transmission of neonatal haemochromatosis is compatible with inheritance of an autosomal recessive trait. In at least one family, family 1 , that an inherited factor determines net transfer of iron from the mother to the fetus was shown by the occurrence of neonatal haemochromatosis in two of four sibs with the disease alternating with healthy children. This was suggested also by the occurrence of maternal iron deficiency anaemia, requiring iron supplementation, that developed only during the affected pregnancies. Studies of the segregation haplotypes in this pedigree showed that if there were to be recessive inheritance of determinants of neonatal haemochromatosis on the short arm of chromosome 6, there is no common background haplotype on 
which the mutation resides, since the affected haplotypes are different between the two copies of $6 \mathrm{p}$ within the affected subjects and are different between family 1 and family 2 . It is however noteworthy that no mutation in the $H F E$ gene was identified on direct sequencing, as described below.

To investigate the role of candidate genes implicated in iron metabolism in the development of neonatal haemochromatosis, we conducted a molecular analysis of the human $H F E$ gene $^{41}$ and the related gene for $\beta_{2}-$ microglobulin, ${ }^{42}$ since their cognate proteins are expressed in the placenta and disordered expression of HFE at cell surfaces mediated by interactions with $\beta_{2}$-microglobulin is associated with systemic iron overload. ${ }^{42-45}$ Since neonatal haemochromatosis occurs at a time of rapid catabolism of haem derived from fetal haemoglobin, ${ }^{46}$ we have also conducted a molecular analysis of the genes encoding the principal haem oxygenase isozymes that are responsible for the breakdown of haem to iron, biliverdin and carbon monoxide. ${ }^{47-49}$ Haem oxygenase 1 (HMOX1) maps to human chromosome $22 \mathrm{q} 13.1$ and is the main inducible form of the enzyme; the homologous isozyme haem oxygenase 2 (HMOX2) is located on chromosome $16 \mathrm{p} 13.3$ and encodes the constitutive isoform..$^{51}$ Knockout mice lacking HMOX1 show growth retardation, diminished resistance to oxidative injury, and develop anaemia with tissue iron deposition..$^{52}$ Mice lacking HMOX2 show pulmonary haemosiderosis and are sensitive to hyperoxia induced tissue injury. ${ }^{53}$ The first case of human haem oxygenase 1 deficiency has recently been described: the 26 month old infant had hepatomegaly, asplenia, abnormal coagulation factors, and endothelial injury in the kidney. ${ }^{54}$ Iron deposition was noted in renal and liver tissue, thus further implicating mutations in HMOX1 and HMOX2 as potential causes of neonatal haemochromatosis.

Since completion of this study, nonsense mutations, representing null alleles of the newly identified transferrin receptor 2 (TfR 2) gene that maps to chromosome $7 \mathrm{q} 22$, have been discovered in adult patients with haemochromatosis otherwise clinically indistinguishable from that resulting from mutations in $H F E .^{55}{ }^{56}$ The indolent nature of the iron storage and degree of tissue injury resulting from this disorder does not resemble neonatal haemochromatosis, and thus TfR 2 is an unlikely candidate gene for the infantile disease. We also describe a consanguineous family with four affected members and the occurrence of disease in one of three nonidentical triplets as well as in maternal half sibs. Caution is required, however, in advising an individual family about the pattern of inheritance and the likelihood of disease recurrence. Although in our series there was no report of neonatal haemochromatosis in generations previous to those of the parents, the formal possibility remains that some cases of the disease could be the result of digenic inheritance in which a rare mutant allele only causes the condition in combination with a much more common polymorphic variant, not necessarily in the same gene. An example of this phenomenon is given by erythropoietic protoporphyria which shows both recessive and digenic inheritance patterns..$^{57}{ }^{58}$ In our current series, two families with neonatal haemochromatosis recapitulate published reports of recurrent disease in maternal half-sibs, in some cases occurring after donor insemination that proceeded after genetic counselling. ${ }^{28}$ Clearly the possibility of recurrent disease in half sibs must always be considered and an assumption of autosomal recessive inheritance of neonatal haemochromatosis in any given pedigree could well prove to be erroneous and lead to inappropriate reproductive decisions. Here we provide additional evidence for a maternal autoantibody factor in two pedigrees and a mode of transmission suggesting matrilineal inheritance compatible with mitochondrial defects as recently reported in two pedigrees. ${ }^{59}$ We also report here one family in which neonatal haemochromatosis occurred in paternal half sibs.

The present study provides strong evidence to exclude neonatal iron storage disease resulting from mutations in genes encoding human HFE, $\beta_{2}$-microglobulin, and haem oxygenases 1 and 2 . To identify further putative disease loci responsible for the inheritance of haemochromatosis in those cases with transmission suggesting inheritance as an autosomal recessive trait, a genome wide scan conducted by molecular analysis of DNA samples obtained from first degree relatives and affected subjects described here is under way. Given the burgeoning knowledge about genes indicated in mammalian iron transport and storage as well as emerging information from the human genome project and comparative genomic studies, ${ }^{45}$ we are confident that major loci that predispose to the development of neonatal haemochromatosis will ultimately be identified.

We are indebted to The Children's Liver Disease Foundation, the Grocer's Trust, the Peel Medical Research Trust, and the European Union for research support. Dr David A Rhodes kindly carried out the class I MHC and chromosome $6 \mathrm{p}$ genotyping. Mrs Joan Grantham provided expert secretarial assistance.

1 Online Mendelian Inheritance in Man (OMIM). National Center for Biotechnology information. Available at: http://www3.ncbi.nim.nih.gov/Omim.

2 Kler W, Olesen M. Hepatitis foetalis med perinatal exitus letalis hos 4 soskende. Ugeskr Laeger 1956;118:868-72.

3 Knisely AS. Neonatal hemochromatosis. Adv Pediatr 1992; 39:383-403.

4 Silver MM, Beverley DW, Valberg LS, Cutz E, Phillips J, Shaheed WA. Perinatal hemochromatosis. Clinical, morphologic and quantitative iron studies. Am $\mathcal{f}$ Pathol

5 Laurendean T, Hill JE, Manning GB. Idiopathic neonatal hemochromatosis in siblings: an inborn error of metabolism. Arch Pathol 1961;72:410-23.

6 Witzleben CL, Uri A. Perinatal hemochromatosis: entity or end result? Hum Pathol 1989;20:335-40.

7 Hardy L, Hansen JL, Kushner JP, Knisely AS. Neonatal haemochromatosis. Genetic analysis of transferrinreceptor, $\mathrm{H}$-apoferritin, and $\mathrm{L}$-apoferritin loci and of the human leucocyte antigen class I region. Am F Pathol 1990; 137:149-53.

8 Knisely AS, Magid MS, Dische MR, Cutz E. Neonatal haemochromatosis. Birth Defects 1987;23:75-102.

9 Silver MM, Valberg LS, Cutz E, Lines LD, Philips MJ. Hepatic morphology and iron quantitation in perinatal hepatic morphology and iron quantitation in p

10 Goldfischer S, Grotsky HW, Chang CH, Berman EL, Richert RR, Karmarkar SD, Roskamp JO, Morecki R. Idiopathic neonatal iron storage involving liver, pancreas, 
heart, and endocrine and exocrine glands. Hepatology 1981;1:58-64.

11 Knisely AS, O'Shea PA, Stocks JF, Dimmick JE. Oropharyngeal and upper respiratory mucosal gland siderosis in neonatal hemochromatosis: an approach to biopsy diagnosis. F Pediatr 1988;113:871-4

12 Coletti RB, Clemmons JJW. Familial neonatal hemochromatosis with survival. $\mathcal{F}$ Pediatr Gastroenterol Nutr 1988;7: 39-45.

13 Rand EB, McClenathan DT, Whitington PF. Neonatal haemochromatosis: report of successful orthotopic liver transplantation. F Pediatr Gastroenterol Nutr 1992;15:325-9.

14 Lund DP, Lillehei CW, Kevy S, Perez-Atayde A, Maller E, Treacy S, Vacanti JP. Liver transplantation in newborn liver failure: treatment for neonatal haemochromatosis. Trans-
plant Proc 1993;1:1068-71.

15 plant Proc 1993,1.1068-71.

Maisesan P, Baker A, Ball C, for neonatal haemochromatosis. Arch Dis Child 1995;73: F178-80.

16 Egawa H, Berquist W, Garcia-Klennedy R, Cox K, Knisely AS, Esquivel CO. Rapid development of hepatocellular siderosis after liver transplantation for neonatal hemosiderosis. Transplantation 1996;62:1511-13.

17 Conn HO. Portacaval anastomosis and hepatic hemosiderin deposition: a prospective, controlled investigation: Gastroenterology 1972;62:61-72.

18 Schneider BL. Neonatal liver failure. Curr Opin Pediatr 1996;8:495-501.

19 Schneider BL, Setchell KDR, Whitington PF, Neilson KA, Suchy F. $\Delta^{4}-3$-oxosteroid $5 \beta$-reductase deficiency causing
neonatal liver failure and hemochromatosis. F Pediatr 1994 ; 124:234-8.

20 Kershisnik MM, Knisely AS, Sun CCJ, Andrews JM, Wittwer CT. Cytomegalovirus infection, fetal liver disease, and neonatal hemochromatosis. Hum Pathol 1992;23:107580 .

21 Bove KE, Wong R, Kagen H, Balistreri W, Tabor MW. Exogenous iron overload in perinatal hemochromatosis: a Exogenous iron overload in perinatal hem
case report. Pediatr Pathol 1991;11:389-97.

22 MetMetzman R, Anand A, DeGuilio PA, Knisely AS. Hepatic insufficiency and fibrosis associated with intrauterine parvovirus B19 infection in a newborn premature infant. F Pediar Gastroenterol Nutr 1989;9:112-14

23 Ruchelli ED, Uri A, Dimmick JE, Bove KE, Huff DS, Duncan LM, Jennings JB, Witzelben CL. Severe perinatal liver disease and Down syndrome: an apparent relationship. Hum Pathol 1991;22:1274-80.

24 Taucher SC, Bentjerodt R, Hübner ME, Nazer J. Multiple malformations in neonatal haemochromatosis. $A m \mathcal{F} \mathrm{Med}$ Genet 1994;50:213-14.

25 Bale PM, Kan AE, Dorney SFA. Renal proximal tubular dysgenesis associated with severe neonatal hemosiderotic liver disease. Pediatr Pathol 1994;14:479-89.

26 Verloes A, Lombet J, Lambert Y, Hubert A-F, Deprez M, Fridman V, Gosseye S, Rigo J, Sokal E. Tricho-hepatoenteric syndrome: further delineation of a distinct syndrome with neonatal hemochromatosis phenotype, intractable diarrhea, and hair abnormalities. Am $\mathcal{f}$ Med Genet table diarrhea,

27 Fellman V, Rapola J. Pikho H, Varilo T, Raivio KO Iron-overload disease in infants involving fetal growth retardation, lactic acidosis, liver haemosiderosis, and aminoaciduria. Lancet 1998;351:490-3.

28 Verloes A, Temple IK, Hubert AF, Hope P, Gould S Debauche C, Verellen G, Deville JL, Koulischer L, Soka $\mathrm{EM}$. Recurrence of neonatal haemochromatosis in half-sibs born of unaffected mothers. F Med Genet 1996;33:444-9.

29 Schoenlebe J, Buyon JP, Zitelli BJ, Friedman D, Greco MA, Knisely AS. Neonatal hemochromatosis associated with maternal autoantibodies against Ro/SS-A and La/SS-B ribonucleoproteins. Am $\mathcal{F}$ Dis Child 1993;147:1072-5.

30 Kelly A, Rhodes DA, Roland JM, Schofield P, Cox TM. Hereditary juvenile haemochromatosis: a genetically heterogeneous life-threatening iron-storage disease. $Q \mathcal{F ~ M e d}$ 1998;91:607-18.

31 Rhodes DA, Raha-Chowdhury R, Cox TM, Trowsdale J. Homozygosity for the predominant Cys 282 Tyr mutation and absence of disease expression in hereditary haemoand absence of disease expression in here
chromatosis. f Med Genet 1997;34:761-4.

32 Walker AP, Wallace DF, Partridge J, Bomford AB, Dooley JS. Atypical haemochromatosis: phenotypic spectrum and beta 2 -microglobulin candidate gene analysis. $\mathcal{F}$ Med Genet 1999;36:537-41.

33 Shamieh I, Kibort PK, Suchy FJ, Freese DK. Antioxidant therapy for neonatal iron storage disease. Pediatric Res 1993;33:109A

34 Chase GA, Folstein MF, Breitner JC, Beaty TH, Self SG. The use of life tables and survived analysis in testing genetic hypotheses, with an application to Alzheimer's disease. Am $\mathcal{F}$ Epidemiol 1983;117:590-7.

35 Mura C, Raguenes O, Ferec C. HFE mutations analysis in 711 hemochromatosis probands: evidence for S65C implication in mild form of hemochromatosis. Blood 1999;93: 2502-5.

36 Douabin V, Deugnier Y, Jouanolle A, Moirand R, Macqueron G, Gireau A, Le Gall JY, David V. Polymorphisms in the HFE gene. Hum Hered 1999;49:21-6.
37 de Villiers J, Nico P, Hillermann R, Loubser L, Kotze MJ. Spectrum of mutations in the HFE gene implicated in
haemochromatosis and porphyria. Hum Mol Genet 1999;8: 1517-22.

38 Hayes AM, Jaramillo D, Levy HL, Knisely AS. Neonatal hemochromatosis: diagnosis with MR imaging. AfR 1992; 159:623-5.

39 Müller-Berghaus J, Knisely AS, Zaum R, Vierzig A, Kirn E, Michelk DV, Roth B. Neonatal haemochromatosis: report of a patient with favourable outcome. Eur $\mathcal{f}$ Pediatr 1997;156:296-8.

40 Dalhoj J, Kiaer H, Wiggers P, Grady RW, Jones RL, Knisely AS. Iron storage disease in parents and sibs of infants with

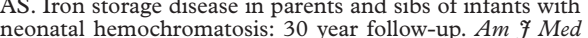
Geonet 1990;37:342-5.

41 Feder JN, Gnirke A, Thomas W, Tsuchihashi Z, Ruddy DA, Basava A, Dormishian F, Domingo R, Ellis MC, Fullan A, Hinton LM, Jones NL, Kimmel BE, Kronmal GS, Lauer P, Lee VK, Loeb AB, Mapa FA, McClelland EE, Meyer NC, Mintier GA, Moeller NN, Moore T, Morikang E, Prass CE, Quintana L, Starnes SM, Schatzman RC, Brunke KJ, class I-like gene is mutated in patients with hereditary haemochromatosis. Nat Genet 1996;13:399-408.

42 De Sousa M, Reimao R, Lacerda R, Hugo P, Kaufmann Porto G. Iron overload in beta 2-microglobulin-deficient mice. Immunology Lett 1994;39:105-11.

43 Feder JN, Tsuchihashi Z, Irrinki A, Lee VK, Mapa FA, Morikang E, Prass CE, Starnes SM, Wolff RK, Parkilla S, Morikang E, Prass CE, Starnes SM, Wolff RK, Parkilla S,
Sly WS, Schatzman RC. The hemochromatosis founder mutation in HLA-H disrupts beta 2 -microglobulin interaction and cell surface expression. F Biol Chem 1997;272: 14025-8.

44 Waheed A, Parkkila S, Zhou XY, Tomatsu S, Tsuchihashi Z, Feder JN, Schatzman RC, Britton RS, Bacon BR, Sly WS. Hereditary haemochromatosis: effects of C282Y and H63D mutations on association with $\beta_{2}$-microglobulin, intracellular processing and cell surface expression of the HFE protein in COS-7 cells. Proc Natl Acad Sci USA 1997; 94:12384-8.

45 Griffiths W, Cox TM. Haemochromatosis: novel gene discovery and the molecular pathophysiology of iron discovery and the molecular pathophysiolo

46 Bratteby LE. Studies on erythro-kinetics in infancy. X1. The change in circulating red cell volume during the first five months of life. Act Paediatr Scand 1968;57:215-26.

47 Tenhunen R, Marver HS, Schmid R. Microsomal heme oxygenase: characterization of the enzyme. F Biol Chem 1969;244:6388-93.

48 London IM, West R, Shemin D, Rittenberg D. On the origin of bile pigment in normal man. F Biol Chem 1950;184:3518.

49 London IM. The conversion of hematin to bile pigment. $\mathcal{F}$ Biol Chem 1950;184:373-6.

50 Seroussi E, Kedra D, Kost-Alimova M, SandbergNordquist A-C, Fransson I, Jacobs JFM, Fu Y, Pan HQ, Roe BA, Imreh S, Dumanski JP. TOM1 genes map to chromosome $22 \mathrm{q} 13.1$ and mouse chromosome $8 \mathrm{C} 1$ and
encode proteins similar to the endosomal proteins HGS encode proteins similar to the endo

51 Kutty RK, Kutty G, Rodriguez IR, Chader GJ, Wiggert B. Chromosomal localization of the human oxygenase genes: heme oxygenase-1 (HMOX1) maps to chromosome 22q12 and heme oxygenase 2 (HMOX2) maps to chromosome 16p 13.3. Genomics 1994;20:513-16.

52 Poss KD, Tonegawa S. Reduced stress defence in heme oxygenase 1-deficient cells. Proc Natl Acad Sci USA 1997;94: 10925-30.

53 Dennery PA, Spitz DR. Yang G, Tatarov A, Lee CS, Shegog ML, Poss KD. Oxygen toxicity and iron accumulation in the lungs of mice lacking heme oxygenase-2. I Clin Invest 1998;101:1001-11

54 Yachie A, Niida Y, Wada T, Igarashi N, Kaneda H, Toma T, Ohta K, Kashahara Y, Koizumi S. Oxidative stress caused enhanced endothelial cell injury in human heme oxygenase-1 deficiency. F Clin Invest 1999;103:129-35.

55 Kawabata H, Yang R, Hirama T, Vuong P T, Kawano S, Gombart AF, Koeffler HP. Molecular cloning of transferrin receptor 2. A new member of the transferrin receptor-like family. F Biol Chem 1999;274:20826-32.

56 Camaschella C, Roetto A, Calli A, De Gobbi M, Garozzo G, Carella M, Majorano N, Totaro A, Gasparini P. The gene TfR 2 is mutated in a new type of haemochromatosis mapping to $7 \mathrm{q} 22$. Nat Genet 2000;25:14-15.

57 Sarkany RP, Alexander GJ, Cox TM. Recessive inheritance of erythropoietic protoporphyria with liver failure. Lancet 1994;344:958-9.

58 Gouya L, Puy H, Lamoril J, Da Silva V, Grandchamp B, Nordmann Y, Deybach JC. Inheritance in erythropoietic protoporphyria: a common wild-type ferrochelatase allelic variant with low expression accounts for clinical manifestation. Blood 1999;93:2105-10.

59 Brown MD, Chitayat D, Allen J, Hosseini J, Litten R, Babul-Hirhi R, Wallace DC. Mitochondrial DNA mutations associated with neonatal hemochromatosis. Am $\mathrm{f}$ Hum Genet 1999;65:A45. 